Brief Report

85:633-640.

2. Lynch PJ, Winkelmann RK. Generalized plane xanthoma and systemic disease. Arch Dermatol 1966;93:639-646.

3. Rosmaninho A, Fernandes I, Guimas A, Amorim I, Selores M. Diffuse plane xanthomatosis associated with monoclonal gammopathy. An Bras Dermatol 2011;86(4 Suppl 1): S50-S52.
4. Taylor JS, Lewis LA, Battle JD Jr, Butkus A, Robertson AL, Deodhar $S$, et al. Plane xanthoma and multiple myeloma with lipoprotein--paraprotein complexing. Arch Dermatol 1978; 114:425-431.

5. Loo DS, Kang S. Diffuse normolipidemic plane xanthomas with monoclonal gammopathy presenting as urticarial plaques. J Am Acad Dermatol 1996;35:829-832.

\title{
Docetaxel-Aggravated Psoriasis
}

\author{
Seungkeol Yang, Bo Ri Kim, Chong Won Choi, Sang Woong Youn \\ Department of Dermatology, Seoul National University College of Medicine, Seoul National University Bundang Hospital, Seongnam, Korea
}

\section{Dear Editor:}

A 78-year-old man with a 50-year history of psoriasis presented with generalized erythematous scaly plaques involving the scalp and face (Fig. 1). Over 5 years, the psoriasis had been confined to the hands and feet and controlled using topical agents alone. Three days prior to emergence of the rash, he reported being administered the first dose of docetaxel $90 \mathrm{mg}$ as treatment for prostate cancer. No aggravation of the psoriasis had been observed throughout past 4 years of treatment with antiandrogens and radiotherapy.

At the present visit, the psoriasis area severity index score was 10.4 , and the percentage of body surface area involved was $20 \%$. Given his medical history and clinical features, we concluded that the preexisting psoriasis had exacerbated due to the newly introduced docetaxel treatment. The patient was treated with acitretin at a dose of $20 \mathrm{mg}$ daily and topical calcipotriol/betamethasone dipro-
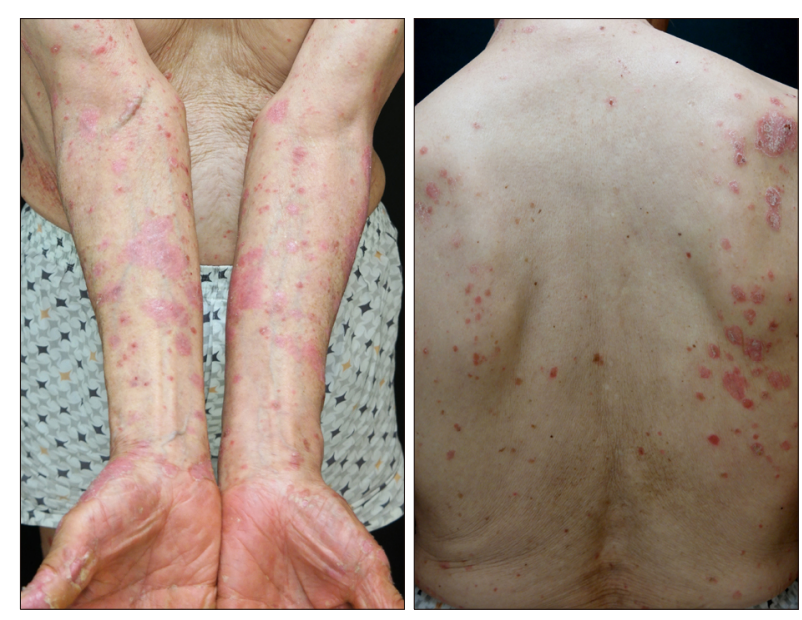

Fig. 1. Scaly erythematous plaques that appeared 3 days after the administration of docetaxel. We received the patient's consent form about publishing all photographic materials.

Received January 22, 2018, Revised March 28, 2018, Accepted for publication April 4, 2018

Corresponding author: Sang Woong Youn, Department of Dermatology, Seoul National University College of Medicine, Seoul National University Bundang Hospital, 82 Gumi-ro 173beon-gil, Bundang-gu, Seongnam 13620, Korea. Tel: 82-31-787-7319, Fax: 82-31-787-4058, E-mail: swyoun@snu.ac.kr ORCID: https://orcid.org/0000-0002-5602-3530

This is an Open Access article distributed under the terms of the Creative Commons Attribution Non-Commercial License (http://creativecommons.org/ licenses/by-nc/4.0) which permits unrestricted non-commercial use, distribution, and reproduction in any medium, provided the original work is properly cited.

Copyright (C) The Korean Dermatological Association and The Korean Society for Investigative Dermatology 
pionate. Docetaxel was discontinued because of a high index of clinical suspicion regarding its role in the aggravation of psoriasis. The psoriasis began to improve, and after 10 weeks of treatment, the patient's condition was controlled without aggravation of the lesions.

Docetaxel is one of the most widely used chemotherapeutic agents in recent years. Various cutaneous adverse effects associated with its use include hand-foot syndrome and radiation recall dermatitis ${ }^{1}$. However, only 2 cases of docetaxel-induced psoriasiform eruptions have been reported $^{2,3}$. These 2 patients demonstrated newly developed psoriasis $2 \sim 4$ days after docetaxel administration. Our patient also demonstrated an adverse reaction within 3 days of administration of the docetaxel-only regimen, which led to a high index of clinical suspicion for docetaxel-induced recurrence of psoriasis. The improvement in psoriasis within a short period of acitretin administration after discontinuation of the docetaxel therapy in this patient also strengthens the causal association between docetaxel administration and the aggravation of psoriasis.

To date, the mechanism of docetaxel-induced skin toxicity remains unclear. The occurrence of hand-foot syndrome is explained to be the result of a direct cytotoxic effect of docetaxel $^{4}$. However, some authors suggest that activation of memory-type inflammatory cell causes radiation recall dermatitis ${ }^{1}$. The theory of direct cytotoxicity was not applicable as the causative mechanism involved in the aggravation of psoriasis in our patient. The activation and subsequent role of resident memory $\mathrm{T}$ cells could be considered a possible contributory pathomechanism. Through some experiments, docetaxel is known not only to increase the population of $\mathrm{CD}^{+}{ }^{+}$and $\mathrm{CD}^{+}{ }^{+} \mathrm{T}$-cells but also to augment their functions in mice ${ }^{5}$. As $\mathrm{CD}^{+}$and $\mathrm{CD} 8^{+}$ T-cells are well known for their role in the pathogenesis of psoriasis, this suggests the possible underlying mechanism of docetaxel-aggravated psoriasis.

To our knowledge, no previous reports have described docetaxel-induced aggravation of psoriasis; the 2 aforementioned reports described cases that presented with de no- vo psoriasis after docetaxel use $\mathrm{e}^{2,3}$. Ours is the first report to describe a case of docetaxel-induced aggravation of psoriasis. This case suggests that careful observation is warranted to detect any exacerbation of the disease following docetaxel administration in patients with underlying psoriasis.

\section{CONFLICTS OF INTEREST}

The authors have nothing to disclose.

\section{ORCID}

Seungkeol Yang, https://orcid.org/0000-0003-4133-6638

Bo Ri Kim, https://orcid.org/0000-0002-2223-1606

Chong Won Choi, https://orcid.org/0000-0001-9994-8819

Sang Woong Youn, https://orcid.org/0000-0002-5602-3530

\section{REFERENCES}

1. Sibaud V, Lebœuf NR, Roche H, Belum VR, Gladieff L, Deslandres $M$, et al. Dermatological adverse events with taxane chemotherapy. Eur J Dermatol 2016;26:427-443.

2. Allende I, González-Hermosa R, Lázaro M, Díaz-Pérez JL. Psoriasis inducida por docetaxel [Docetaxel-induced psoriasis]. Actas Dermosifiliogr 2009;100:629-630. Spanish.

3. Kerob D, Le Maignan C, Vignon-Pennamen MD, Lebbe C. Psoriasis induit par le docétaxel [Docetaxel-induced psoriasis]. Ann Dermatol Venereol 2010;137:738-740. French.

4. Poi MJ, Berger M, Lustberg M, Layman R, Shapiro CL, Ramaswamy B, et al. Docetaxel-induced skin toxicities in breast cancer patients subsequent to paclitaxel shortage: a case series and literature review. Support Care Cancer 2013;21:2679-2686.

5. Kodumudi KN, Woan K, Gilvary DL, Sahakian E, Wei S, Djeu JY. A novel chemoimmunomodulating property of docetaxel: suppression of myeloid-derived suppressor cells in tumor bearers. Clin Cancer Res 2010;16:4583-4594. 